\title{
Nutritional composition of Annona crassiflora pulp and acceptability of bakery products prepared with its flour
}

\author{
Paula VILLELA ${ }^{1}$, Ângela Giovana BATISTA ${ }^{1}$, Nísia Andrade Villela DESSIMONI-PINTO ${ }^{2 *}$
}

\begin{abstract}
Annona crassiflora offers an edible fruit native to the Savanna. This study aimed to develop a flour meal from Annona crassiflora pulp; analyze the chemical composition of the fresh pulp and its flour; develop and verify the acceptance of formulations with different concentrations of the flour of Annona crassiflora pulp. Fruit used were selected and processed. The pulp was dried in an oven at $60-65^{\circ} \mathrm{C} / 48 \mathrm{~h}$. We analyzed the chemical composition, and two formulations of breads were prepared with 10 and $20 \%$ Annona crassiflora pulp. The results showed that the drying of Annona crassiflora pulp enriched its nutritional value. The Annona crassiflora pulp showed important chemical components, as insoluble fibers (pulp and flour), minerals (potassium, calcium, manganese and others) and antioxidant compounds. The formulations were well-accepted in a sensory point of view and proved to be a good alternative to the exploitation of the fruit.
\end{abstract}

Keywords: Savanna fruit; drying; sensory.

\section{Introduction}

Annona species are usually consumed as fresh fruit, but they are also widely used in semi-processed and processed products, especially desserts. With increasing world demand for exotic flavors and healthy food, the use of Annona fruit is also likely to increase (PINTO et al., 2005).

Regarding the Brazilian Savanna, Annona crassiflora is a minor fruit used in traditional medicine and it has been receiving research attention (ALMEIDA; AGOSTINI-COSTA; SILVA, 2008). Annona crassiflora belongs to the family Annonaceae and receives many popular names, namely: araticum, araticumdo-cerrado, ariticum, articum, marolo, bruto, cabeça-de-negro, pinha-do-cerrado and pasmada (LORENZI, 2002; LUZIA; JORGE, 2013).

Fruiting occurs from January to March, 30 to 200 fruits per plant and each fruit has 0.5 to $4.5 \mathrm{~kg}$ (CENTRO..., 1999). When ripe, fruit of Annona crassiflora has brown color and can be collected from the ground. During this phase are perishable and should be consumed immediately or processed. They can also be collected from the tree when showing signs of opening the peel. The advantage of this collection of pre-maturity is getting the fruit after ripening, since the fall of the ripe fruit causes cracking, facilitating the attack of insects. In relation to the quality of the pulp there are two kinds of fruit: the pink pulp, softer and sweeter, and the yellowish pulp, lighter, acid and smooth less (BRASIL, 2002).

Annona crassiflora is widely used in human medicine as for treatment of various diseases such as diarrhea, rheumatism and syphilis. It contains acetogenins that have cytotoxic, antiparasitic and antitumogenic properties (VILAR et al., 2008). Besides medicinal uses, Annona crassiflora in natura pulp is very popular and has a potential for the food industry (SOARES JÚNIOR et al., 2007, ROCHA et al., 2004, 2008). Roesler et al. (2007a, b) observed the antioxidant potential of bioactive components widely reported as potent antioxidants such as ascorbic, caffeic, quinic, and ferulic acids, xanthoxylin, rutin, caffeoyltartaric acid, caffeoyl glucose and [quercetin + hexose+pentose $-\mathrm{H}]^{-1}$ compounds identified from Annona crassiflora pulp, seeds and peel. The antioxidant potential can be further extended to exploit the possible application as natural antioxidant for cosmetics, supplements, and functional ingredients for food products.

The literature shows that consumption of fruit of Annona crassiflora or its products can add nutritional value to food (CARAMORI; LIMA; FERNANDES, 2004) being an alternate source of nutrients (SILVA et al., 2008). One hundred grams of pulp contains $154.58 \mathrm{kcal}$ energy, $1.14 \mathrm{~g}$ protein, $2.30 \mathrm{~g}$ lipids, 76.73 moisture, $5.21 \mathrm{pH}, 2.96 \mathrm{~g}$ total acidity, $12.00{ }^{\circ}$ Brix total solids and 0.85 ash (MARTINS, 2006).

Annona fruit are very perishable and short postharvest life (PINTO et al., 2005). Therefore, $A$. crassiflora also require efficient storage techniques and are lacking studies regarding chemical and technological exploitation of Annona crassiflora flour (ACF).

The ACF quality obtained from conventional dehydration and lyophilization were evaluated by Corrêa et al. (2011). Dehydrated products proved to be sources of dietary fiber and derivatives from oleic and palmitic acids, and can be used during periods between harvests of Araticum fruit.

In addition, the literature data have showed safe drying temperatures ranging from 40 to $70^{\circ} \mathrm{C}$ to different raw materials 
(FERREIRA; PENA, 2010; COELHO; AZEVEDO, 2012; SOUZA et al., 2012; ZANATTA; SCHLABITZ; ETHUR, 2010).

Silva et al. (2008) related that there are few scientific studies on the chemical and nutritional composition of native Savanna fruit.

The aim of this study was to evaluate the chemical and mineral composition of Annona crassiflora pulp and its flour, as well as the influence of adding A crassiflora flour on sensory acceptance of bakery products.

\section{Materials and methods}

\subsection{Preparation of Annona crassiflora fruit and flour}

A. crassiflora fruit were purchased in the city of Diamantina, Minas Gerais State, Brazil. Ripe fruit were selected by the absence of cracks and signs of deterioration. Fruit were washed and the pulp was separated manually from the seeds and peel.

After processing, part of the fruits were dried in a forced air oven at $60 \pm 5{ }^{\circ} \mathrm{C}$, for 48 hours until moisture content between

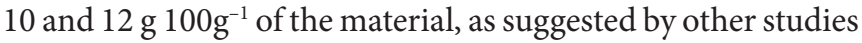
(ZANATTA; SCHLABITZ; ETHUR, 2010; FERREIRA; PENA, 2010; COSTA et al., 2012). Then, samples were crushed in a grinder with a sieve aperture of $0.5 \mathrm{~mm}$, homogenized and stored in plastic bags at $-10{ }^{\circ} \mathrm{C}$ and protected from light prior to analysis and preparation of the formulations, resulting in the A. crassiflora flour (ACF).

\subsection{Chemical determination}

Proximate composition (ASSOCIATION..., 2005): moisture was determined through a forced air oven at $105 \pm 5^{\circ} \mathrm{C}$ to obtain a constant weight, ash was determined by burning organic matter present in food at $550 \pm 5{ }^{\circ} \mathrm{C}$. The protein was determined by Kjeldahl method; the ether extract or lipids were determined by continuous ether extraction using the Soxhlet extractor (Tecnal TE 044-5/50 model) device; total, insoluble and soluble dietary fibers were determined by the enzymatic gravimetric method of Prosky et al. (1988); total carbohydrates were calculated as the mass balance difference $\left(\mathrm{g} 100 \mathrm{~g}^{-1}\right)$ related others components, the energy value was obtained using Atwater factors (BUCHHOLZ; SCHOELLER, 2004).

Determination of Minerals: calcium, zinc, potassium, magnesium, iron, phosphorus and manganese were determined by atomic absorption spectrometry (Shimadzu UV 1240) with acetylene flame, method of Sarruge and Haag (1974) and Fiske and Subbarow (1925). The extracts (dry matter) were obtained by nitro-perchloric digestion. Phosphorus was determined according to AOAC (ASSOCIATION..., 1990), calcium, magnesium, copper, iron, manganese and zinc by atomic absorption spectrophotometry (AAS7 model), and potassium by flame photometry (AFP-100 model).

Determination of total acidity (TA): The total acidity was determined by titration of the pulp and flour with $0.01 \mathrm{~N} \mathrm{NaOH}$. The results were expressed as $\mathrm{g}_{\text {citric acid }} 100 \mathrm{~g}^{-1}$ (INSTITUTO..., 2005).
Total polyphenol, flavonoid and vitamin $C$ contents: Phenolic compounds were expressed as mg GAE $100 \mathrm{~g}^{-1}$ and were extracted by the method of Swain and Hillis (1959), using $80 \%$ methanol and identified using the Folin-Ciocalteau method (ZIELINSKI; KOZLOWSKA, 2000). Total flavonoids were quantified by Zhishen, Mengcheng and Jianming (1999), using the pyrocatechin as standard and expressed as mg $100 \mathrm{~g}^{-1}$. Vitamin $\mathrm{C}$ was determined by the Tillmans method, expressed as mg $100 \mathrm{~g}^{-1}$ according to the Institute Adolfo Lutz (INSTITUTO..., 2005).

\subsection{Use of Annona crassiflora pulp flour (AF)}

We developed two formulations of bread, the first containing 10 and 20\% ACF (F10 and F20, respectively), replacing the wheat flour. A control formulation was also developed, without the test flour, as described in Table 1.

\subsection{Baking method}

The baking used was the direct method, consisting of the stages: mix (25 min), weigh and division of the dough (100 $\pm 10 \mathrm{~g}$ ), casting, fermentation ( $1 \mathrm{~h}$ and $30 \mathrm{~min}$ ) and baked in gas oven (Dako, 103L) at $180 \pm 20^{\circ} \mathrm{C}$ for 40 minutes.

\subsection{Sensory analysis}

Panelists of the sensory evaluation were students and staff of the Federal University of Jequitinhonha and Mucuri Valleys (UFVJM), with no relationship of subordination to the researchers. They signed an informed consent according to Resolution 196/96 of the Ministry of Health (BRASIL, 1996), protocol 032/2008 in the process of the Research Ethics Committee of UFVJM.

Panelists $(n=37)$ were nonsmokers, of different ages, both sexes, randomly selected, untrained. The preference test was done according to Carneiro and Minin (2006). In the acceptance test, participants $(n=37)$ received an evaluation form containing a 5 point-hedonic scale, in which the highest score represented [five] "I like very much" and the minimum score represented [one] "I dislike very much" (MONTEIRO, 1984). The acceptability index (AI\%) of the formulation was determined and calculated according to Teixeira, Meinert and Barbetta (1987) as follow:

Table 1. Ingredients of formulations evaluated containing different ratios of Annona crassiflora pulp flour.

\begin{tabular}{lccr}
\hline \multirow{2}{*}{ Ingredients (\%) } & \multicolumn{3}{c}{ Formulations $^{*}$} \\
\cline { 2 - 4 } Sugar & Control & F10 & \multicolumn{1}{c}{ F20 } \\
Eggs & 30.49 & 30.49 & 30.49 \\
Milk & 6.35 & 6.35 & 6.35 \\
Margarine & 12.70 & 12.70 & 12.70 \\
AF & 1.52 & 1.52 & 1.52 \\
Wheat Flour & - & 4.57 & 9.15 \\
Yeast & 45.74 & 41.17 & 36.59 \\
\hline
\end{tabular}

${ }^{*}$ F10: formulation with $10 \%$ replacement of wheat flour by ACF; F20: formulation with $20 \%$ of ACF. 


$$
A I \%=\frac{\text { Average acceptance score }}{\text { Maximum acceptance score }} \times 100
$$

\subsection{Statistical analysis}

Results of acceptance tests were subjected to ANOVA and Tukey's test at $5 \%$ probability level for comparison between means, using the statistical software SISVAR (FERREIRA, 2003). The results of the ordering test were subjected to Friedman's test and Hollander and Wolfe (1973) tables at 5\% significance levels.

\section{Results and discussion}

The flour concentrated nutrients from the A. crassiflora pulp, showing high levels of dietary fiber, carbohydrates, ash and total polyphenols (Table 2).

The moisture from the Annona crassiflora pulp was close to findings of Almeida, Agostini-Costa and Silva (2008)

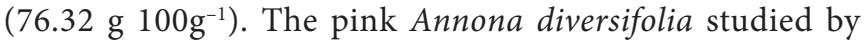
Julián-Loaeza et al. (2011) also showed similar moisture content

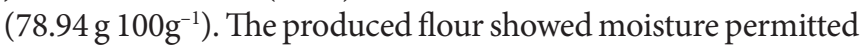
by current law (BRASIL, 2005).

In general fruit pulp are not considered good sources

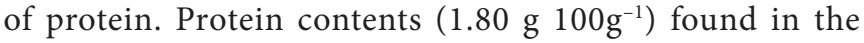
A. crassiflora pulp studied by Roesler et al. (2007a) were higher than in this study. However, Almeida, Agostini-Costa and Silva

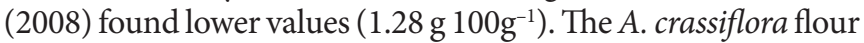
concentrated protein from pulp and this could contribute about $12 \%$ needs of a $60 \mathrm{~kg}$, 30-year-old adult (INSTITUTE..., 2004).

The ether extract of the A. crassiflora pulp was lower than that observed by Silva et al. (2008) and Roesler et al. (2007a). The ACF showed high amounts of crude fat or ether extract

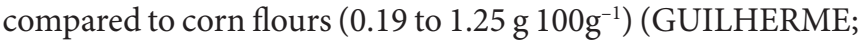
JOKL, 2005). Common flours used in bakery products possess different amounts of fat; the value found in ACF is among those verified to wheat and oat flour used in Brazil and USA (PADOVANI et al., 2007). In addition, the fatty acid profile

Table 2. Average contents of chemical composition of the fresh Annona crassiflora and its flour (ACF).

\begin{tabular}{lcc}
\hline \multicolumn{1}{c}{ Components $^{\star}$} & Pulp $(\mathrm{g} \%)$ & AF $(\mathrm{g} \%)$ \\
\hline Moisture & $78.92 \pm 2.65$ & $11.32 \pm 1.37$ \\
Crude Protein & $1.38 \pm 0.01$ & $5.80 \pm 1.06$ \\
Ether Extract & $1.39 \pm 0.02$ & $5.85 \pm 0.78$ \\
Total dietary fiber & $3.50 \pm 0.25$ & $14.72 \pm 2.22$ \\
Insoluble dietary fiber & $2.95 \pm 0.11$ & $12.41 \pm 2.54$ \\
Soluble dietary fiber & $0.55 \pm 0.03$ & $2.31 \pm 0.45$ \\
Ash & $1.59 \pm 0.32$ & $6.69 \pm 0.75$ \\
Carbohydrate & $13.22 \pm 2.36$ & $55.61 \pm 4.32$ \\
Calorie (Kcal \%) & $70.91 \pm 4.28$ & $298.29 \pm 7.04$ \\
Total acidity (gac citric \%) & $0.34 \pm 0.03$ & nd \\
Total polyphenol (mgGAE \%) & $423.94 \pm 11.64$ & $1245.44 \pm 11.64$ \\
Total flavonoid (mg \%) & $63.14 \pm 0.58$ & $201.32 \pm 8.92$ \\
Vitamin C (mg \%) & $21.34 \pm 3.58$ & nd \\
Total Carotenoid (mg \%) & nd & $1.13 \pm 0.04$ \\
\hline
\end{tabular}

${ }^{*}$ Mean of five replicates \pm standard deviation. nd $=$ non-determined. of fat from ACF should be investigated, given that $79 \%$ monounsaturated fatty acids from the pulp of A. crassiflora is represented by oleic acid (ALMEIDA; AGOSTINI-COSTA; SILVA, 2008). It is known that regular consumption of monounsaturated fatty acids (oleic acid) may reduce the risk of cardiovascular disease, since they are associated with reduction in plasma total cholesterol and LDL-cholesterol, without lowering HDL-cholesterol and cause lipid oxidation (SPOSITO et al., 2007).

The content of total dietary fibers was lower than found by Silva et al. (2008). However, compared with conventional flours, the ACF showed high values of total dietary fibers (PADOVANI et al. (2007). Regarding the type of fibers, the A. crassiflora flour showed significant amounts, especially about the insoluble fraction. Insoluble fibers have important physiological effects on human health. They increase volume and softening of feces and the defecation frequency, reducing the intestinal transit time (INSTITUTE..., 2002). Moreover, Adam et al. (2001) examined flours with high insoluble fiber contents and found that these were effective in lowering LDL-cholesterol in experimental animals, demonstrating the functional effects.

Additionally, the values found for ash were higher than the A. crassiflora pulp cited in the literature (ROESLER et al., 2007a; ALMEIDA, AGOSTINI-COSTA; SILVA, 2008; SILVA et al., 2008), and conventional bakery flours (wheat and oat) (PADOVANI et al., 2007). The flour also showed significant levels of minerals, as observed in Table 3.

Carbohydrate content of the A. crassiflora pulp was superior to that registered by Silva et al. (2008), but the caloric values were lower. Hypothetically, $100 \mathrm{~g}$ ACF contributes about $15 \%$ of total caloric value of an individual with a diet of $2000 \mathrm{kcal} /$ day.

Other fruit of the family Annonaceae has total acidity

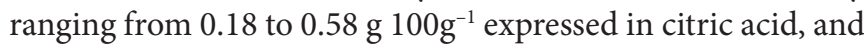

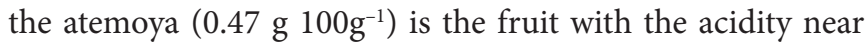
to that found in A. crassiflora (MARCELLINI et al., 2003). Julián-Loaeza et al. (2011) reported $0.34 \mathrm{~g}_{\text {citric acid }} 100 \mathrm{~g}^{-1}$ in the deep pink A. diversifolia. Soares Júnior et al. (2007) found

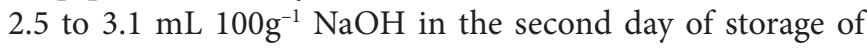
minimally processed $A$. crassiflora pulp, which represents 0.16 to $0.20 \mathrm{~g}_{\text {citric acid }} 100 \mathrm{~g}^{-1}$, less than that of $A$. crassiflora pulp evaluated.

Table 3. Mineral composition of the Annona crassiflora pulp and flour.

\begin{tabular}{lcc}
\hline \multicolumn{1}{c}{ Minerals $^{\text {a }}$} & Pulp $(\mathrm{mg} \%)$ & ACF $(\mathrm{mg} \%)$ \\
\hline Potassium $(\mathrm{K})$ & $177.07 \pm 18.62$ & $744.90 \pm 19.85$ \\
Calcium $(\mathrm{Ca})$ & $27.92 \pm 4.12$ & $117.45 \pm 2.92$ \\
Phosphorus $(\mathrm{P})$ & $14.76 \pm 4.03$ & $62.09 \pm 2.77$ \\
Magnesium $(\mathrm{Mg})$ & $14.23 \pm 2.69$ & $59.86 \pm 2.84$ \\
Copper $(\mathrm{Cu})$ & $0.92 \pm 0.09$ & $39.22 \pm 2.63$ \\
Zinc $(\mathrm{Zn})$ & $0.81 \pm 0.02$ & $3.41 \pm 0.24$ \\
Iron $(\mathrm{Fe})$ & $0.49 \pm 0.02$ & $2.06 \pm 0.07$ \\
Manganese $(\mathrm{Mn})$ & $0.44 \pm 0.02$ & $1.85 \pm 0.02$ \\
\hline
\end{tabular}

${ }^{a}$ Mean of five replicates \pm standard deviation 
Polyphenol contents found in the A. crassiflora pulp were higher than observed by Julián-Loaeza et al. (2011) in

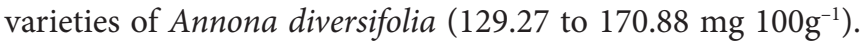

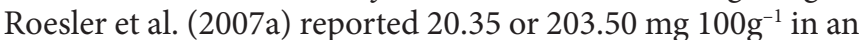
ethanolic extract of the A. crassiflora pulp, and Caramori, Lima and Fernandes (2004) found $5.96 \mathrm{mg} \mathrm{g}^{-1}$ dry weight. Thus, it is possible that methanol is a solvent more efficient in extracting polyphenols from the pulp of $A$. crassiflora, since the results of this study are also higher than found in ethanolic extracts (ROESLER et al., 2007b).

In a study with different temperatures to dry A. crassiflora pulp, Costa et al. (2012) showed that there was no change in flavonoid and polyphenol contents when dried at $60{ }^{\circ} \mathrm{C}$. The flavonoids have been studied for their antioxidant activity (WILLIAMS; SPENCER; RICE-EVANS, 2004; LUIS; ALLER, 2008), and some studies have already proven their action in reducing oxidation of LDL-cholesterol and therefore to decrease the risk of cardiovascular disease (ZERN; WEST; FERNANDEZ, 2003). Varieties of A. diversifolia studied by Julián-Loaeza et al. (2011) showed higher levels of flavonoids (107.41 to $152.04 \mathrm{mg}$ $100 \mathrm{~g}^{-1}$ ) compared to A. crassiflora, however the amount of flavonoids found in the pulp flour is higher.

Besides the participation in the biological metabolism, vitamin $C$ is a potent water-soluble antioxidant and its content tends to decrease with fruit ripening (CHITARRA; CHITARRA, 2005). The vitamin C content found by Julián-Loaeza et al.

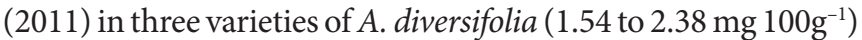
were lower than found in A. crassiflora, which suggests a higher antioxidant potential in relation to other species.

Carotenoids may act as antioxidants associated with reduced risk of many chronic degenerative diseases (TRUMBO; ELLWOOD, 2006; VOUTILAINEN et al., 2006). The $A$. crassiflora pulp studied by Almeida, Agostini-Costa and Silva

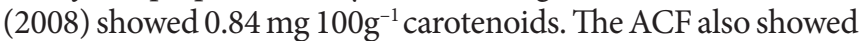
significant amounts of these compounds.

The highlighted mineral components in the analyzed materials were potassium, calcium, phosphorus and manganese (Table 3).

The three varieties of Annona diversifolia fruit showed high

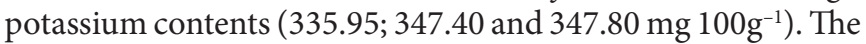
amount of potassium is also higher than those found in oat and wheat flours (PADOVANI et al., 2007). Thus, ACF could be considered a great source of potassium: 100g ACF would supply $15.85 \%$ daily needs of an adult (INSTITUTE..., 2004).

The A. crassiflora pulp studied by Silva et al. (2008) presented similar values of calcium $\left(29.0 \mathrm{mg}^{100 \mathrm{~g}^{-1}}\right)$. For a person (19 to 50 years) with daily needs of $1000 \mathrm{mg}$ calcium per day, the addition of $100 \mathrm{~g}$ ACF to the diet would contribute with $11.75 \%$ nutritional recommendations (INSTITUTE..., 1997). But it must be considered the presence of anti-nutritional compounds such as phytates and oxalates, which impair the absorption of this mineral (BUZINARO; ALMEIDA; MAZETO, 2006).

The Annona species showed values of phosphorus ranging

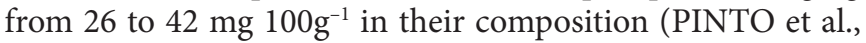
2005), which were higher than the those found in A. crassiflora.
The consumption of $100 \mathrm{~g} \mathrm{day}^{-1}$ of ACF would contribute $8.87 \%$ phosphorus needs of an adult (INSTITUTE..., 1997).

Moreover, magnesium, the fourth most abundant mineral in A. crassiflora, participates in several important metabolic processes (HE et al., 2006; SCHULZE et al., 2007). The study of He et al. (2006) provides a prospective evidence that magnesium intake is inversely associated with incident metabolic syndrome and its components in healthy young adults. Thus, the consumption of $A$. crassiflora pulp or ACF can also bring beneficial effects to human health due to its magnesium content. A. crassiflora studied by Almeida, Agostini-Costa and Silva (2008) showed a higher content of magnesium $(24.2 \mathrm{mg}$ $100 \mathrm{~g}^{-1}$ ) compared to this study. The deep pink A. diversifolia fruit evaluated by Julián-Loaeza et al. (2011) obtained the concentration of magnesium (14.01 mg $\left.100 \mathrm{~g}^{-1}\right)$ near to that of Annona crassiflora.

In this way, the consumption of copper and zinc is essential to maintain enzymatic activities in the body (BUZADŽIĆ et al.,2002). Oat in the USA contains amounts of zinc close to that found in $\mathrm{ACF}$, but the values of copper is the opposite (PADOVANI et al., 2007). The consumption (100 $\left.\mathrm{g} \mathrm{day}^{-1}\right)$ of A. crassiflora pulp and

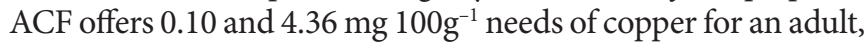
respectively (INSTITUTE..., 2002).

Silva et al. (2008) found $0.79 \mathrm{mg}^{100 \mathrm{~g}^{-1}} \mathrm{zinc}$ and $0.43 \mathrm{mg}$ $100 \mathrm{~g}^{-1}$ iron in the A. crassiflora pulp, values close to the present study. Julián-Loaeza et al. (2011) registered lower values of

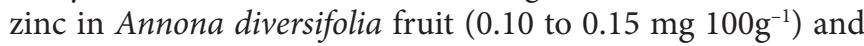
Almeida, Agostini-Costa and Silva (2008) observed higher

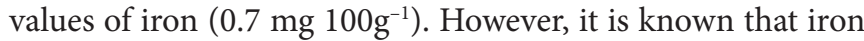
from plant foods is not completely bioavailable, and probably the highest rate of iron intake will not result in greater absorption, because it depends on its bioavailability in the meal, or presence of anti-nutrients that can decrease the absorption (AQUINO; SALVINO, 2009).

Manganese is a mineral with vital role in a body, for the operation of the nervous system, formation of normal structures and maintenance and normal reproduction. It is part of many enzymes and interferes with the use of fats, the functioning of the liver, pancreas and adrenal glands (CHITARRA; CHITARRA, 2005). One hundred grams of $A$. crassiflora flour per day would supply little more than $100 \%$ requirements (AI) for manganese of an adult or older person (INSTITUTE..., 2002), which helps in carrying out vital functions of this mineral. Thus, the consumption of ACF could enhance the source of minerals such as potassium, calcium, manganese. However further studies are required to elucidate the interaction between minerals or other dietary compounds.

The Table 4 lists the results of statistical analysis, indicating no significant difference between the sum of preference orders and acceptance means by the hedonic scale test.

In the preference test conducted by Rocha et al. (2008), the yogurt with $25 \%$ of $A$. crassiflora sweet was preferred instead 20 and $30 \%$. In this study, there was no statistical difference in the preference test, indicating that it is possible to add the ACF in bakery products at concentrations even higher than those studied. 
Table 4. Results of acceptance and ordering tests of the breads prepared with different proportions of Annona crassiflora flour ( $\mathrm{n}=37)$.

\begin{tabular}{ccccc}
\hline Tests & Results & Control & F10 & \\
\hline Ordering & Sum of orders* & $67^{\mathrm{a}}$ & $78^{\mathrm{a}}$ & $73^{\mathrm{a}}$ \\
& Mean of scores* & $4.11^{\mathrm{a}}$ & $4.03^{\mathrm{a}}$ & $4.08^{\mathrm{a}}$ \\
Acceptance & AI (\%) & $82.20^{\mathrm{a}}$ & $80.60^{\mathrm{a}}$ & $81.60^{\mathrm{a}}$ \\
\hline
\end{tabular}

${ }^{\star}$ Sum of orders followed by the same letter are not significantly different by Friedman test $(\mathrm{p}<0.05) .{ }^{* *}$ Acceptance means followed by the same letter are not significantly different by Tukey's test $(\mathrm{p}<0.05)$.

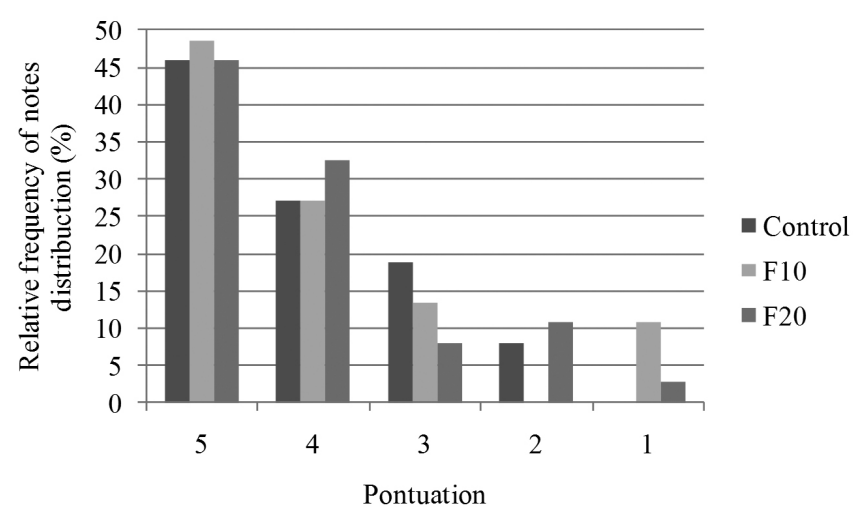

Figure 1. Percentage of scores assigned to breads made with AF in the 5 point- scale test $(n=37)$.

The average of hedonic scale test indicate acceptance scores " 4 - I liked" and " 5 - I liked very much", acceptance also evidenced by the AI above $80 \%$ in the three formulations. Rocha et al. (2008) also found high acceptance scores for yogurt with A. crassiflora sweet, unlike Rocha et al. (2004), that found average scores between 3 (indifference) and 4 (acceptance), in the 5 point-hedonic scale.

Figure 1 illustrates that the F10 received the highest score percentage "5- I liked very much", and F20 showed the highest percentage (78.38\%) of the acceptance scores.

The scores distribution among the panelists also indicate acceptance of the experimental formulations. Thus, it is possible to produce bakery products with 10 or $20 \%$ ACF instead of wheat flour.

According to Cheong et al. (2010), A. muricata fruit have many volatile flavor compounds. Thus, research on the quantitative descriptive analysis and intentions to purchase/ consumption are necessary to map the best sensory profile of the products studied, since volatile flavor compounds in $A$. crassiflora pulp could influence the acceptance thereof.

\section{Conclusions}

The drying process is crucial to preserve the nutritional characteristics from fresh fruit.

The A. crassiflora pulp and flour offer significant amounts of fiber, carbohydrates, minerals and antioxidants such as polyphenols, vitamin $\mathrm{C}$ and carotenoids.

The breads have good acceptability, AI above $80 \%$ in the three formulations.

\section{References}

ADAM, A. et al. Whole wheat and triticale flours with differing viscosities stimulate cecal fermentations and lower plasma and hepatic lipids in rats. Journal of Nutrition, v. 131, n. 6, p. 17701776, 2001.

ALMEIDA, S. P.; AGOSTINI-COSTA, T. S.; SILVA, J. A. Frutas nativas do cerrado: caracterização físico-química e fonte potencial de nutrientes. In: SANO, S. M.; ALMEIDA, S. P.; RIBEIRO, J. F. Cerrado, ecologia e flora. Brasília: Embrapa Informação Tecnológica, 2008.

AQUINO, J. S.; SALVINO, E. M. Estimativa da porcentagem de biodisponibilidade e frequência de ferro nos cardápios do restaurante de um Hospital Universitário. Acta Scientiarium Technology, v. 31, p. 6-18, 2009.

ASSOCIATION OF OFFICIAL ANALYTICAL CHEMISTS - AOAC. Official methods of the association of official analytical chemists. 15th ed. Washington: AOAC, 1990.

ASSOCIATION OF OFFICIAL ANALYTICAL CHEMISTS - AOAC. Official method of analysis. 18th ed. Washington: AOAC, 2005.

BRASIL. Conselho Nacional de Saúde. Resolução n. 196, de 10 de outubro de 1996. Aprovas as diretrizes e normas regulamentadoras de pesquisas envolvendo seres humanos. Diário Oficial da República Federativa do Brasil, Brasília, DF, out. 1996.

BRASIL. Ministério da Saúde. Secretaria de Políticas de Saúde. Coordenação-Geral da Política de Alimentação e Nutrição. Alimentos regionais brasileiros. Brasília: Ministério da Saúde, 2002.

BRASIL. Agência Nacional de Vigilância Sanitária - ANVISA. Resolução RDC no 263, de 22 de setembro de 2005. Aprova o "REGULAMENTO TÉCNICO PARA PRODUTOS DE CEREAIS, AMIDOS, FARINHAS E FARELOS”. Diário Oficial da República Federativa do Brasil, Brasília, v. 1, p. 368-369, 2005.

BUCHHOLZ, A. C.; SCHOELLER, D. A. Is a calorie a calorie? American Journal of Clinical Nutrition, v. 79, n. 5, p. 899S-906S, 2004. PMid:15113737.

BUZADŽIĆ, B. et al. Effect of supplementation with $\mathrm{Cu}$ and $\mathrm{Zn}$ on antioxidant enzyme activity in the rat tissues. Food Research International, v. 35, n. 2-3, p. 217-220, 2002. http://dx.doi. org/10.1016/S0963-9969(01)00187-9

BUZINARO, E. F.; ALMEIDA, R. N. A.; MAZETO, G. M. F. S. Biodisponibilidade do cálcio dietético. Arquivos Brasileiros de Endocrinologia e Metabologia, v. 50, n. 5, p. 852 861, 2006. PMid:17160208. http://dx.doi.org/10.1590/S000427302006000500005

CARAMORI, S. S.; LIMA, C. S.; FERNANDES, K. F. Biochemical characterization of selected plant species from Brazilian savannas. Brazilian Archives of Biology and Technology, v. 47 , n. 2, p. 253-259, 2004. http://dx.doi.org/10.1590/S151689132004000200013 
CARNEIRO, J. D. S.; MININ, V. P. R. Testes de preferência. In: MININ, V. P. R. (Org.). Análise sensorial: estudos com consumidores. Viçosa: Ed. UFV, 2006.

CHEONG, K. W. et al. Equilibrium headspace analysis of volatile flavor compounds extracted from soursop (Annona muricata) using solidphase microextraction. Food Research International, v. 43, n. 5, p. 1267-1276, 2010. http://dx.doi.org/10.1016/j.foodres.2010.03.001

CHITARRA, M. I. F.; CHITARRA, A. B. Pós-colheita de frutos e hortaliças: fisiologia e manuseio. 2. ed. Lavras: UFLA, 2005. 249 p.

COELHO, E. M.; AZEVEDO, L. C. Comparação entre técnicas de secagem para obtenção de farinha a partir da casca de manga cv. Tommy atkins. In: CONNEPI - CONGRESSO NORTE NORDESTE DE PESQUISA E INOVAÇÃO, 7., 2012, Palmas. Anais... Palmas: IFTO, 2012.

CORRÊA, S. C. et al. Evaluation of dehydrated marolo (Annona crassiflora) flour and carpels by freeze-drying and convective hot-air drying. Food Research International, v. 44, n. 7, p. 23852390, 2011. http://dx.doi.org/10.1016/j.foodres.2011.02.052

FERREIRA, D. F. SISVAR 4.6 sistema de análises estatísticas. Lavras: UFLA, 2003.

FERREIRA, M. F. P.; PENA, R. S. Estudo da secagem da casca do maracujá amarelo. Revista Brasileira de Produtos Agroindustriais, v. 12, n. 1, p. 15-28, 2010.

FISKE, C. H.; SUBAROW, Y. The colorimetric determination of phophorus. The Journal of Biological Chemistry, v. 66, p. 375-400, 1925.

CENTRO BRASILEIRO DE REFERENCIA E APOIO CULTURAL - CEBRAC. Oportunidades de geração de renda no Cerrado: texto para discussão. Brasília: Programa de Pequenos Projetos - GEF/PNUD, 1999.

COSTA , A. M. et al. Estabilidade de antioxidantes na farinha de araticum processada a diferentes temperaturas. In: CONGRESSO BRASILEIRO DE FRUTICULTURA, 22., 2012, Bento Gonçalves. Anais... Bento Gonçalves: SBF, 2012. Disponível em: <http:// ainfo.cnptia.embrapa.br/digital/bitstream/item/71213/1/

CD416AnaMaria1.pdf>. Acesso em: 19 set. 2013.

GUILHERME, F. F. P.; JOKL, L. Emprego de fubá de melhor qualidade protéica em farinhas mistas para produção de biscoitos. Ciência e Tecnologia de Alimentos, v. 25, n. 1, p. 63-71, 2005. http://dx.doi. org/10.1590/S0101-20612005000100011

$\mathrm{HE}, \mathrm{K}$. et al. Magnesium intake and incidence of metabolic syndrome among young adults. Circulation, v. 113, n. 13, p. 1675-1682, 2006. PMid:16567569. http://dx.doi.org/10.1161/ CIRCULATIONAHA.105.588327

HOLLANDER, M.; WOLFE, D. A. Nonparametric statistical methods. New York: Wiley, 1973.

INSTITUTO ADOLFO LUTZ - IAL. Normas analíticas: métodos químicos e físicos para análise de alimentos. 4. ed. São Paulo: IAL, 2005.

INSTITUTE OF MEDICINE - IM. Dietary reference intakes for calcium, phosphorus, magnesium, vitamina $\mathrm{D}$ and fluoride. Washington: National Academy Press, 1997.

INSTITUTE OF MEDICINE - IM. Dietary reference intakes for vitamin $A$, vitamin $K$, arsenic, boron, chromium, copper, iodine, iron, manganese, molybdenum, nickel, silicon, vanadium, and zinc. Washington: National Academy Press, 2002.

INSTITUTE OF MEDICINE - IM. Dietary reference intakes for water, potassium, sodium, chloride, and sulfate. Washington: National Academy Press, 2004.
INSTITUTE OF MEDICINE - IM. Dietary reference intakes for energy, carbohydrate, fiber, fat, fatty acids, cholesterol, protein, and amino acids. Washington: National Academy Press, 2005.

JULIÁN-LOAEZA, A. P. et al. Chemical composition, color, antioxidant activity of three varieties of Annona diversifolia Safford fruits. Industrial Crops and Products, v. 34, n. 2, p. 1262-1268, 2011. http://dx.doi.org/10.1016/j.indcrop.2010.06.012

LORENZI, H. Árvores brasileiras: manual de identificação e cultivo de plantas arbóreas nativas do Brasil. 4. ed. Nova Odessa: Plantarum, 2002.

LUIS, D. A.; ALLER, R. Papel de los flavonoides del té en la protección cardiovascular. Anales de Medicina Interna, v. 25, n. 3, p. 105107, 2008. PMid:18560675. http://dx.doi.org/10.4321/S021271992008000300001

LUZIA, D. M. M.; JORGE N. Bioactive substance contents and antioxidant capacity of the lipid fraction of Annona crassiflora Mart. seeds. Industrial Crops and Products, v. 42, p. 231-235, 2013. http://dx.doi.org/10.1016/j.indcrop.2012.05.027

MARCELLINI, P. S. et al. Comparação físico-química e sensorial da atemóia com a pinha e a graviola produzidas e comercializadas no estado de Sergipe. Alimentos e Nutrição, v. 14, n. 2, p. 187189, 2003.

MARTINS, B. A. Avaliação físico-química de frutos do cerrado in-natura e processados para a elaboração de multimisturas. 2006. 85 f. Dissertação (Mestrado em Ecologia e produção sustentável)-Universidade Católica de Goiás, Goiânia, 2006. Disponível em: <http://tede.biblioteca.ucg.br/tde_busca/arquivo. php? codArquivo=187>. Acesso em: 19 set. 2013.

MONTEIRO, C. L. B. Técnicas de avaliação sensorial. 2. ed. Curitiba: UFPR, 1984. $101 \mathrm{p}$.

PADOVANI, R. M. et al. Comparison of proximate, mineral and vitamin composition of common Brazilian and US foods. Journal of Food Composition and Analysis, v. 20, n. 8, p. 733-738, 2007. http://dx.doi.org/10.1016/j.jfca.2007.03.006

PINTO, A. C. Q. et al. Annona species. Southampton: International Centre for Underutilised Crops, 2005. chapt. 6, 7 and 11.

PROSKY, L. et al. Determination of insoluble, soluble, and total dietary fiber in foods and food products: interlaboratory study. Journal of Association of Official Analytical Chemists, v. 71, n. 5, p. $1017-$ 1023, 1988. PMid:2853153.

ROCHA, C. et al. Iogurte de leite de búfala sabor frutos do Cerrado. Boletim do Centro de Pesquisa e Processamento de Alimentos, v. 22, n. 1, p. 97-106, 2004.

ROCHA, C. et al. Elaboração e avaliação de iogurte sabor frutos do Cerrado. Boletim do Centro de Pesquisa e Processamento de Alimentos, v. 26, n. 2, p. 255-266, 2008

ROESLER, R. et al. Antioxidant activity of Annona crassiflora: Characterization of major components by electrospray ionization mass spectrometry. Food Chemistry, v. 104, n. 3, p. 10481054, 2007a. http://dx.doi.org/10.1016/j.foodchem.2007.01.017

ROESLER, R. et al. Atividade antioxidante de frutas do cerrado. Ciência e Tecnologia de Alimentos, v. 27, n. 1, p. 53-60, 2007b. http://dx.doi. org/10.1590/S0101-20612007000100010

SARRUGE, J. R.; HAAG, H. P. Análises químicas em plantas. Piracicaba: ESALQ, 1974. 56 p.

SCHULZE, M. B. et al. Fiber and magnesium intake and incidence of type 2 diabetes: a prospective study and meta-analysis. Archives of Internal Medicine, v. 167, n. 9, p. 956-965, 2007. PMid:17502538. http://dx.doi.org/10.1001/archinte.167.9.956 
SILVA, M. R. et al. Caracterização química de frutos nativos do cerrado. Ciência Rural, v. 38, n. 6, p. 1790-1793, 2008. http://dx.doi. org/10.1590/S0103-84782008000600051

SOARES JÚNIOR, M. S. et al. Filmes plásticos e ácido ascórbico na qualidade de araticum minimamente processado. Ciência Rural, v. 37 , n. 6 , p. 1779-1785, 2007. http://dx.doi.org/10.1590/S010384782007000600043

SOUZA, D. S. et al. Elaboração de farinha instantânea a partir da polpa de fruta-pão (Artocarpus altilis). Ciência Rural, v. 42, n. 6, p. 1123-1129, 2012.

SPOSITO, A. C. et al. IV Diretriz brasileira sobre dislipidemias e prevenção da aterosclerose: Departamento de Aterosclerose da Sociedade Brasileira de Cardiologia. Arquivos Brasileiros de Cardiologia, v. 88, p. 2-19, 2007. Suplemento 1.

SWAIN, T.; HILLIS, W. G. The phenolic constituents of Prunus domestica. I. - The quantitative analysis of phenolic contituents. Journal of the Science of Food and Agriculture, v. 10, p. 63-68, 1959. http://dx.doi. org/10.1002/jsfa.2740100110

TEIXEIRA, E.; MEINERT, E. M.; BARBETTA, P. A. Análise sensorial de alimentos. Florianópolis: Ed. UFSC, 1987.

TRUMBO, P. R.; ELLWOOD, K. C. Lutein and zeaxanthin intakes and risk of agerelated macular degeneration and cataracts: an evaluation using the food and drug administration's evidence-based review system for health claims. American Journal of Clinical Nutrition, v. 84, n. 5, p. 971-974, 2006. PMid:17093145.

VILAR, J. B. et al. Assessment of the mutagenic, antimutagenic and cytotoxic activities of ethanolic extract of araticum (Annona crassiflora Mart. 1841) by micronucleus test in mice. Brazilian Journal of Biology, v. 68, n. 1, p. 141-147, 2008. http://dx.doi. org/10.1590/S1519-69842008000100020
VOUTILAINEN, S. et al. Carotenoids and cardiovascular health. American Journal of Clinical Nutrition, v. 83, n. 6, p. 12651271, 2006. PMid:16762935.

WILLIAMS, R. J.; SPENCER, J. P.; RICE-EVANS, C. Flavonoids: antioxidants or signalling molecules? Free Radical Biology and Medicine, v. 36, n. 7, p. 838-849, 2004. PMid:15019969. http:// dx.doi.org/10.1016/j.freeradbiomed.2004.01.001

ZANATTA, C. L.; SCHLABITZ C; ETHUR, E. M. Avaliação físicoquímica e microbiológica de farinhas obtidas a partir de vegetais não conformes à comercialização. Alimentos e Nutrição, v. 21, n. 3, p. 459-468, jul./set. 2010. Disponível em: <http://servbib. fcfar. unesp.br/seer/index.php/alimentos/article/viewFile/1044/1044>. Acesso em: 03 jan. 2013.

ZERN, T. L.; WEST, K. L.; FERNANDEZ, M. L. Grape polyphenols decrease plasma triglycerides and cholesterol accumulation in the aorta of ovariectomized guinea pigs. The Journal of Nutrition, v. 133, n. 7, p. 2268-2272, 2003 PMid:12840191.

ZHISHEN, J.; MENGCHENG, T.; JIANMING, W. The determination of flavonoid contents in mulberry and the scavenging effects on superoxide radicals. Food Chemistry, v. 64, n. 4, p. 555-559, 1999. http://dx.doi.org/10.1016/S0308-8146(98)00102-2

ZIELINSKI, H.; KOZLOWSKA, H. Antioxidant activity and total phenolics in selected cereal grains and their different morphological fractions. Journal of Agricultural and Food Chemistry, v. 48, n. 6, p. 2008-2016, 2000. PMid:10888490. http://dx.doi.org/10.1021/ jf990619o 